\title{
A model of the relationship between strategic orientation and product innovation under the mediating effect of customer knowledge management
}

\section{Emad Alani}

Azman Hashim International Business School, Universiti Teknologi

Malaysia

Malaysia

emadalani1984@yahoo.com

\section{Suzilawati Kamarudin}

Azman Hashim International Business School, Universiti Teknologi

Malaysia, Malaysia

College of Business, University of Business and Technology Jeddah,

KSA

surilawati@utm.my

Laith Alrubaiee

Uruk University

Iraq

alrubaiee_laith@yahoo.com

\section{Razieh Tavakoli}

University of Texas

USA

ra-zieb.tavakoli@mavs.uta.edu

Abstract. Product innovation has been considered one of the main drivers of value creation, the prerequisite for market success, and often for business survival, particularly in high-tech industries. At this, strategic orientation is seen as the principle directed to achieve superior innovation. Miles and Snow's strategic orientation has been one of the most important and intensively studied typologies throughout the world, even though empirical evidence on its particular propositions is not clear enough. Direct and indirect impact of strategic orientation on product innovation can be influenced by certain environmental and organizational contexts as well as other capabilities, e.g., customer knowledge management (CKM). Studies carried out on strategic typologies and CKM have usually reported mixed results. The purpose of this conceptual paper is to provide a framework to enhance the understanding and to investigate the relationship 
between strategic orientation and product innovation and the mediating effect of $\mathrm{CKM}$, at the same time contributing to the existing number of valuable researches that provide the much needed knowledge in understanding product innovation phenomenon. Hence, there is a need to conduct an empirical study to validate the proposed conceptual framework and to ascertain the relationship among different variables in this framework.

Keywords: strategic orientation, miles and snow strategic orientations, customer knowledge management, product innovation.

JEL Classification: G21, L26, O16

\section{INTRODUCTION}

In a global business environment, product innovation is the prerequisite for market success, and often for company's survival (Stevanović, Marjanović \& Štorga, 2016). Both entrepreneurs and policy makers have been focusing on the ways through which they can boost their innovation (Haneda \& Ito, 2018). However, there are also quite many studies asserting that success or failure of business companies is primarily related to the concept of "strategic orientation" (Miles \& Snow, 1978). Companies' strategic orientation makes it easy for them to adopt and be focused on innovation. This affects managers when they are to determine directives and make necessary decisions (Cássia \& Zilber, 2016). However, research points out differences in the importance of different strategic orientations for innovation (Grinstein, 2008).

Some studies confirm that those organizations that hold an acceptable level of knowledge management competency generally employ the available resources more effectively as compared to others, hence showing higher degree of innovation and performing better (Belkahla \& Triki, 2011). Consequently, to remain effective in market competition, companies need to have sufficient customer knowledge resources, especially at the level of management (Falasca, Zhang, Conchar, \& Li, 2017). Recently, scholars started to add knowledge management and intellectual capital to the list of factors that can be antecedents of innovation (Darroch \& McNaughton, 2002; Voit, Tkachenko \& Oleshkevich, 2018). Limited attention has been paid to direct investigation of the link between customer knowledge management though. We were not able to find any studies that specifically examine the potential mediating effects of customer knowledge management on the relationship between strategic orientation and product innovation. To this end, the studies carried out regarding possible mediating effects of knowledge management have identified a number of significant missing pieces (Zheng, Yang \& McLean, 2010). Therefore, our study is addressing these research gaps.

Our findings and arguments provide evidence from the critical investigation on the relationship between Miles and Snow strategic orientation and product innovation and the mediating effect of customer knowledge management in it.

\section{LITERATURE REVIEW}

\subsection{Strategic orientation}

In recent two decades, a great deal of research in the strategic management and entrepreneurship fields of study has been conducted on strategic orientation (Hussain, Rahman, \& Shah, 2016). Therefore, we can find the strategic orientation a set of guiding principles capable of shaping the managerial decision-making 
procedure of an organization and helps the managers to effectively configure the organizational resources and the way they interact with the market (Cássia \& Zilber, 2016). To realize the companies' level of sensibility, they have to behave within a global context in a totally strategic way to effectively compete or to achieve competitive advantages preserve them determinedly (Tutar, Nart, \& Bingöl, 2015). However, strategic orientation can be also described as organization-specific, culture-based, and complex capabilities that show the philosophy of the organization in the way it carries out its business activities and make interactions with external environment (Zhou, Yim \& Tse, 2005).

Strategic orientation of a market-driven company significantly indicates the way it performs business; this also includes how the managers perceive the success of new products (Gatignon \& Xuereb, 1997). In addition, strategic orientation can be referred to as the company's wide and joint performances supported by communicating, interpreting, adopting, and enacting the information in an effective way (Menguc \& Auh, 2005). Consequently, strategic orientation gives a wide-ranging outline of the company's strategies while leaving the details regarding the content and implementation of the strategies uncompleted (Slater, Olson \& Hult, 2006).

\subsection{Miles and snow strategic orientation typology}

A great deal of research has been carried out on strategic types in particular and strategic issues in general (Mantere, Schildt, \& Sillince, 2012). The former includes the Miles and Snow (1978) typology, the "growth strategies" of (Ansoff, 1965), the Ansoff and Stewart (1967) typology, Mintzberg's typology (H. Mintzberg, 1973; Henry Mintzberg, 1979), Porter's strategies (Porter, 1980, 1985), strategic orientation suggested by Venkatraman (1989), and Market orientation (Kohli \& Jaworski, 1990; Narver \& Slater, 1990). Among the above cases, that of Miles and Snow (1978) has been able to attract more attention, hence being widely investigated across the world. They has been one of the most important and intensively studied typologies on this subject throughout the world, most popular and extensively studied typology of strategic choices and most frequently empirically proven strategic classifications (Ingram, Kraśnicka, WronkaPośpiech, Głód, \& Głód, 2016).

However, this typology was principally focused on the influences of top managers on the overall direction and vision of the organization (O'Regan \& Ghobadian, 2005). Miles and Snow incorporated the organizational strategies, structures, and process variables into a certain framework, which resulted in a multifaceted typology. Their viewpoint was that strategy can adjust the connection between a company and its environment; they also maintained that internal processes and structures must be well matched with the strategy in order for the company to succeed. Furthermore, considering the way organizations give response to a varying environment and how they adapt the organization to the environment, Miles and Snow (1978) classified the business organizations into four strategic categories, i.e., prospector, defender, analyzer, and reactor.

- Prospector companies persistently attempt to hunt opportunities appearing in market and regularly examine the responses that can be potentially given to emergent trends in the business environment (Miles \& Snow, 1978).

- Defender companies attain competitive advantages through further succeeding within existing market with prevailing products. They bear the minimum degree of uncertainty in comparison with the companies of other types (Gnjidić, 2014).

- Analyzer companies though take an in-between position; they show features of both defenders and prospectors. These companies are keen to follow the pioneers' footsteps and, at the same 
time, they rely upon a resilient position in some crucial categories of service/product in case of a firm core of customers (Pleshko, Heiens \& Peev, 2014).

- Reactor companies determine the degree to which the top managers await instructions on the way they can give response to changes occurring to their environment. They may change, but only once the environment obliges them to change (Flink, 2015).

Accordingly, the framework suggested by Miles and Snow (1978) can be still known as the most efficient and useful system available to classify the organizations' strategies (Song, Nason, \& Di Benedetto, 2008).

\subsection{Customer knowledge management}

Knowledge in today's economy is known as a milestone in sustainable growth and achievement of competitive advantages (Cepeda-Carrion, Martelo-Landroguez, Leal-Rodríguez, \& Leal-Millán, 2017). Customer knowledge management also refers to the set of dynamic skills and organizational practices that are connected to creation, conservation, and transferring of the knowledge about the company's customers (Alegre, Sengupta, \& Lapiedra, 2013). For that reason, a great deal of research has been carried out highlighting the fundamental role knowledge management is playing now in competitiveness of small, medium, and large organizations (Cerchione \& Esposito, 2017). Accordingly, knowledge management became a significant capability for managers in creating customer value (Cepeda-Carrion et al., 2017). The reason for such significance is the fact that knowledge is considered as a key strategic resource.

However, companies need to be well adapted to the customers' expectations and requirements in a way to be more attractive compared to the rivals and enhance customers' satisfaction level (Sanaz, Mona, \& Hossein, 2017). In this respect, an efficient method for being adapted to the customers' varied needs is the use of customers' knowledge and to manage this knowledge as a significant implied resource (Nastaran, Reza, \& Mohammad, 2014). This has put customer in the place of the key source of knowledge for any company. In addition, customer's knowledge considerably affects corporate management; thus, it is necessary for companies to absorb this knowledge and apply it to the enhancement of their performance quality (Tseng \& Fang, 2015).

Consequently, we can find customer knowledge management at a focal point of research as enabling of innovation performance in general and show product innovation in specific (Belkahla Hakimi, Triki, \& Mjahed Hammami, 2014).

To that end, for the purpose of interacting with customers, some particular systems must be developed aiming at satisfying the customers' requirements. In addition, an appropriate environment should be prepared with a better access to knowledge and the customers' ideas; such knowledge should be applied to an innovation process (Sanaz et al., 2017). To do this, a knowledge-sharing platform can be constructed within an interactive and developing environment. This platform will be capable of not only helping the organization do its business, but also forming a proper environment for sharing and exchanging existing knowledge between the organization and its customers (Nastaran et al., 2014).

\subsection{Product innovation}

In current turbulent environment, wherein global competitions are increasingly augmenting and the life cycle of products is getting shorter and shorter, there is an increasing need for innovation. Researchers and practitioners have firmly acknowledged the significance of innovation for organizations to survive and grow (Fossas-Olalla, Minguela-Rata, López-Sánchez, \& Fernández-Menéndez, 2015). In such a rapidlymoving business world, constantly innovating is a key factor that pushes an organization toward 
competitiveness (Zaefarian, Forkmann, Mitrega, \& Henneberg, 2017). Product innovation, can be defined as "The introduction of a good or service that is new or significantly improved in terms of its characteristics or intended uses" (Potecea \& Cebuc, 2011).

Essentially, product innovation is of a high importance to business environment since it helps companies develop novel market segments and expand their current market segments and product portfolios (Slotegraaf \& Pauwels, 2008). Moreover, practicing product innovation, organizations will be capable of expanding and growing into new areas. Though, to do this, a company may need also greater resources (Sharma, Davcik, \& Pillai, 2016). As a result, product innovation is also known as a crucial factor in corporate renewal, as well as the 'engine of renewal' (Bowen, Clark, Holloway, \& Wheelwright, 1994).

In addition, product innovation offers a mechanism that can be implemented in order to access resources (e.g., people, knowledge, or technology) to make innovation; these resources cannot be owned or controlled by companies themselves (Huang \& Rice, 2012). In this context, product innovation mainly depends upon an organization's capability of mobilizing other actors in business scene, including suppliers or customers, as well as the capability of managing in such strategic orientation (Zaefarian et al., 2017).

\section{THEORETICAL FRAMEWORK AND HYPOTHESIS DEVELOPMENT}

\subsection{Strategic orientation and product innovation}

Research points to differences in the importance of different strategic orientations to innovation (Grinstein, 2008a). In case of environments suffering from instability, companies with strategic orientation can deal with shortage of resource and competence and also they are able to overcome the existing difficulties through the use of innovative activities in a way to develop their innovation process (Cássia \& Zilber, 2016). In addition, to effectively manage the serious problems, particularly the contagious ones, in a dynamic organization, managers need to be efficiently engaged in strategic orientation. It cannot be performed merely as a simple trade-off between definite types of strategy or a choice for a distinct strategic direction (Pawlowsky \& Schmid, 2012). The strategic orientation selected considerably varies the service innovation. Companies in the analyzer, defender, and prospector categories generally show a higher quality innovative performance compared to those in the reactor category. Although, any meaningful difference has not been observed in the innovative performance of the companies in the first three categories mentioned above (Liu, 2010). Hence the following hypotheses are postulated:

H1: Strategic Orientations (Defenders, Prospectors, Analyzers and Reactors) positively influences Product Innovation.

\subsection{Strategic orientation and customer knowledge management}

A company's strategic orientation significantly affects how to determine valuable areas of knowledge, the areas of knowledge that need to be assimilated, and the areas that need to be applied (Lane, Koka, \& Pathak, 2006). Furthermore, findings of Ritala, Henttonen, Salojärvi, Sainio, and Saarenketo (2013) confirmed that adopting various strategic orientations has influence on the degree to which companies employ various external sources of knowledge. They also showed that if a company is able to adopt an efficient market orientation, it will achieve effective market knowledge and it can manage customer knowledge effectively (Lin, Che, \& Ting, 2012). Similarly, externally market orientation focused to the customers' needs, accumulation and analysis of information and knowledge close to the market has a positive impact on knowledge management (Pawlowsky \& Schmid, 2012). Therefore: 
H2: Strategic Orientations (Defenders, Prospectors, Analyzers and Reactors) positively influences Customer Knowledge Management.

\subsection{Customer knowledge management and product innovation}

Customer knowledge is a significantly effective role on the companies' knowledge process, particularly in regard to the concept of innovation (Massaro, Handley, Bagnoli, \& Dumay, 2016). As argued in literature, knowledge in itself cannot be a competitive advantage resource; the fact is that knowledge must be efficiently involved in the production of new knowledge. As a result, organizational knowledge and managing this knowledge are firmly linked to the organizational learning, unlearning, and innovation (Dasgupta, Sahay, \& Gupta, 2009).

In the same direction, knowledge and processes on the basis of knowledge play an outstanding role to foster innovation. In addition, available knowledge can be effective differently on innovation activities (Nieves, Quintana, \& Osorio, 2016). Researchers of this field of study believe that the process of customer knowledge determines the product innovation of a company (Yu-Pei, Meng-Ying \& Li-Ke, 2016). Accordingly, implementing the customer knowledge management is an important process that can get customers involved and make use of their ideas and knowledge to make innovation (Taherparvar, Esmaeilpour \& Dostar, 2014). The following hypothesis are advanced:

H3: Customer Knowledge Management positively influences Product Innovation.

\subsection{The mediating effect of customer knowledge management on the relationship between strategic orientations and product innovation}

Scholars indicate that customer knowledge management competence plays mediating role in translating a company's market orientation to business performance (Rollins \& Halinen, 2005). Furthermore, scholars have shown that knowledge management mediates between entrepreneurial orientation and innovation performance (Madhoushi, Sadati, Delavari, Mehdivand, \& Mihandost, 2011). Besides, as stated by Kaya and Patton (2011), the organizational resources that are based on knowledge have shown a mediating role in relationships between learning orientation and innovation performance.

In such a view, knowledge management is found a mediator between organizational effectiveness and organization's structure and culture (Tung, 2004; Jasinskas et al., 2015). Likewise, knowledge management has been confirmed to have a mediating role between human capital and innovation performance (Alshekaili \& Boerhannoeddin, 2011; Poór et al., 2018; Bilan et al., 2017). Similarly, knowledge management is completely a mediator in the influences of organizational culture upon organizational effectiveness, while it is a partial mediator in the influences of organizational strategy and structure upon the organizational effectiveness (Zheng et al., 2010; Mishchuk et al., 2016). Moreover, previously-conducted studies have asserted that market knowledge and customer knowledge management play an important mediating role in relationships between market orientation and product innovation (Lin et al., 2012). Therefore, we advance the following hypotheses:

H4: Customer Knowledge Management mediate the relationship between Strategic Orientations and Product Innovation.

Therefore, Figure 1 illustrates the conceptual framework proposed to guide this study. 
H4

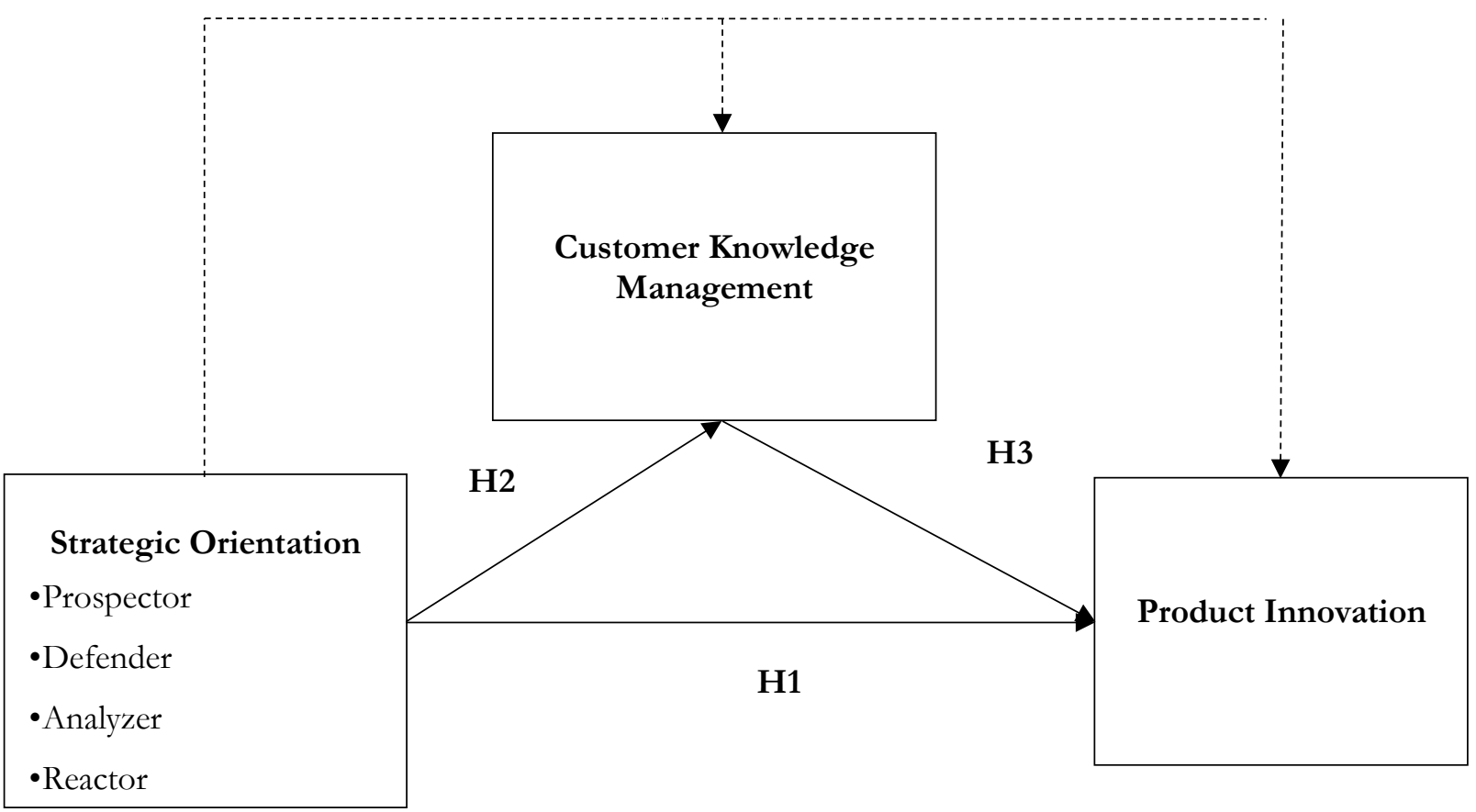

$\longrightarrow$ Direct Relationship

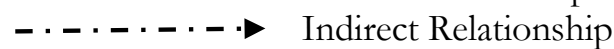

Figure 1. Proposed conceptual model

\section{IMPLICATIONS}

The main objective of this paper is to provide a better understanding on the product innovation within the organizational context. For this purpose, a conceptual formwork was proposed, which can give effective support and help to performance of future research in this field of study. Thus, the finding of this paper will be able to enhance the body of knowledge from both the perspective of an academic and managerial domain.

\subsection{Managerial implications}

I. This proposed conceptual framework attempts to demonstrate how strategic orientations, customer knowledge management can increase product innovation.

II. This study will provide understanding for top management about what are the most suitable strategic orientations practices that lead a superior product innovation, which is a key element in the achievement of competitive advantages. Since different strategic orientations have different effects on product innovation, the top management will pay more attention in the strategic orientations that has the highest impact on product innovation.

III. This study will help management to give more attention to customer knowledge management because of its direct effects upon the product innovation and the mediating effect that can be exerted on the relationships between strategic orientation and product innovation. 


\subsection{Academic implications}

I. Increase the number of published academic research paper on product innovation which will increase the understanding on the product innovation phenomenon.

II. Serve as a foundation for future product innovation study in the area of strategic orientation and customer knowledge management in the working environment.

III. The proposed conceptual framework in the present study can be used from various scholars for a wider arena, especially in high technology context to develop competitive advantage

\section{CONCLUSION}

Studies posits that there is a great attention paid by scholars to different types of relationships such as Miles and Snow strategic orientation typology, customer knowledge management and product innovation; however, you can hardly find studies analyzing all these factors simultaneously. Hence, this proposed conceptual framework will have rectified this shortcoming.

Some studies argued the relationship between strategic orientation and innovation generates contradictory outcomes (Baker \& Sinkula, 1999; Deshpandé \& Farley, 2004). However, Ferraresi, Quandt, dos Santos, and Frega (2012) reported 23 of totally 36 studies i.e., 64\%, indicated a positive correlation, whereas the remaining explored only a weak or non-significant correlation. Due to multidimensional of strategic orientation it is not easy to directly compare the impact of the alternate strategic orientations effects on innovation. This issue may have contribution to inconsistency of findings across studies (Spanjol, Mühlmeier, \& Tomczak, 2012). Therefore, many gaps need for investigating the ways a firm is able to take the innovation advantages for the purpose of renewal of their strategic orientations and deal with increasingly unpredictable environment that is hard to understand (Cássia \& Zilber, 2016).

In general, the organizational strategy has been left out in research conducted on knowledge management. Within the knowledge management antecedents list, though little studies have investigated the impacts of strategy on knowledge management (Watkins \& Marsick, 1996), just a simple relationship has been reported and evaluated (Zheng et al., 2010). To this end, scholars from a general point of view, believe that practices of knowledge management must be well matched with the organizational context to provide competitive edge for the company (Rastogi, 2000). On the other hand, the studies carried out upon the possible mediating effects of knowledge management have identified a number of significant missing pieces (Zheng et al., 2010). Since knowledge management definition is broadly accepted, this is really a hard task to measure the knowledge management and determine the ways it affects the organization's outcome, e.g., performance and innovation (Darroch \& McNaughton, 2002).

This framework with its focus on strategic orientation, customer knowledge management influence on product innovation will contribute to the body of knowledge in the aspect of product innovation phenomenon. Thus, it is recommended that further empirical study be undertaken to validate this conceptual framework which will prove to be valuable in adding to the body of knowledge at this critical point of time.

\section{ACKNOWLEDGEMENT}

The authors are thankful to University library, Azman Hashim International Business School, Universiti Teknologi Malaysia for their help and support. 


\section{REFERENCES}

Alegre, J., Sengupta, K., \& Lapiedra, R. (2013). Knowledge management and innovation performance in a high-tech SMEs industry. International Small Business Journal, 31(4), 454-470.

Alshekaili, S. A. R., \& Boerhannoeddin, A. (2011). Human capital approach towards enhancing innovation performance in Omani industrial firms: The role of knowledge management. Progress in Business Innovation \& Technology Management, 1, 23-33.

Ansoff, H. I. (1965). Corporate strategy: business policy for growth and expansion: McGraw-Hill Book.

Ansoff, H. I., \& Stewart, J. M. (1967). Strategies for a technology-based business. Harvard business review, 45(6), 71-83.

Baker, W. E., \& Sinkula, J. M. (1999). The synergistic effect of market orientation and learning orientation on organizational performance. Journal of the Academy of Marketing Science, 27(4), 411-427.

Belkahla Hakimi, W., Triki, A., \& Mjahed Hammami, S. (2014). Developing a customer knowledge-based measure for innovation management. European Journal of innovation management, 17(3), 349-374.

Belkahla, W., \& Triki, A. (2011). Customer knowledge enabled innovation capability: proposing a measurement scale. Journal of knowledge management, 15(4), 648-674.

Bilan, Y., Mishchuk, H., \& Dzhyhar, T. (2017). Human capital factors and remuneration: analysis of relations, modelling of influence. Business: Theory and Practice, 18, 208-214.

Bowen, H. K., Clark, K. B., Holloway, C. A., \& Wheelwright, S. C. (1994). Development projects: The engine of renewal. Harvard Business Review, 72(5), 110-120.

Cássia, A. d. R., \& Zilber, S. N. (2016). Strategic orientation and innovative activities: an analysis using the PINTEC data from 1998 to 2011. Gestão \& Produção, 23(3), 447-458.

Cepeda-Carrion, I., Martelo-Landroguez, S., Leal-Rodríguez, A. L., \& Leal-Millán, A. (2017). Critical processes of knowledge management: An approach toward the creation of customer value. European Research on Management and Business Economics, 23(1), 1-7.

Cerchione, R., \& Esposito, E. (2017). Using knowledge management systems: A taxonomy of SME strategies. International journal of information management, 37(1), 1551-1562.

Darroch, J., \& McNaughton, R. (2002). Examining the link between knowledge management practices and types of innovation. Journal of intellectual capital, 3(3), 210-222.

Dasgupta, M., Sahay, A., \& Gupta, R. (2009). The role of knowledge management in innovation. Journal of Information \& Knowledge Management, 8(04), 317-330.

Deshpandé, R., \& Farley, J. U. (2004). Organizational culture, market orientation, innovativeness, and firm performance: an international research odyssey. International Journal of Research in Marketing, 21(1), 3-22.

Falasca, M., Zhang, J., Conchar, M., \& Li, L. (2017). The impact of customer knowledge and marketing dynamic capability on innovation performance: an empirical analysis. Journal of Business \& Industrial Marketing, 32(7), 901912.

Ferraresi, A. A., Quandt, C. O., dos Santos, S. A., \& Frega, J. R. (2012). Knowledge management and strategic orientation: leveraging innovativeness and performance. Journal of knowledge management, 16(5), 688-701.

Flink, C. M. (2015). Multidimensional conflict and organizational performance. The American Review of Public Administration, 45(2), 182-200.

Fossas-Olalla, M., Minguela-Rata, B., López-Sánchez, J.-I., \& Fernández-Menéndez, J. (2015). Product innovation: When should suppliers begin to collaborate?. Journal of Business Research, 68(7), 1404-1406.

Gatignon, H., \& Xuereb, J.-M. (1997). Strategic orientation of the firm and new product performance. Journal of Marketing Research, 77-90.

Gnjidić, V. (2014). Researching the dynamics of Miles and Snow's strategic typology. Management: journal of contemporary management issues, 19(1), 93-117.

Grinstein, A. (2008a). The effect of market orientation and its components on innovation consequences: a metaanalysis. Journal of the Academy of Marketing Science, 36(2), 166-173.

Haneda, S., \& Ito, K. (2018). Organizational and human resource management and innovation: Which management practices are linked to product and/or process innovation? Research Policy, 47(1), 194-208.

Huang, F., \& Rice, J. (2012). Openness in product and process innovation. International Journal of Innovation Management, 16(04), 1250020. 
Hussain, J., Rahman, W., \& Shah, F. A. (2016). Market orientation and performance: the interaction effect of entrepreneurial orientation. Pakistan Journal of Commerce and Social Sciences, 10(2), 388.

Jasinskas, E., Emeljanovas, A., \& Bilan, Y. (2015). Features of Qualification Improvement of Human Resources in Public and Private Sector. Transformations in Business \& Economics, 14(2B), 462-481.

Ingram, T., Kraśnicka, T., Wronka-Pośpiech, M., Głód, G., \& Głód, W. (2016). Relationships Between Miles and Snow Strategic Types and Organizational Performance in Polish Production Companies. Journal of Management and Business Administration, 24(1), 17-45.

Kaya, N., \& Patton, J. (2011). The effects of knowledge-based resources, market orientation and learning orientation on innovation performance: An empirical study of Turkish firms. Journal of international development, 23(2), 204219.

Kohli, A. K., \& Jaworski, B. J. (1990). Market orientation: the construct, research propositions, and managerial implications. The Journal of Marketing, 1-18.

Lane, P. J., Koka, B. R., \& Pathak, S. (2006). The reification of absorptive capacity: A critical review and rejuvenation of the construct. Academy of management review, 31(4), 833-863.

Lin, R.-J., Che, R.-H., \& Ting, C.-Y. (2012). Turning knowledge management into innovation in the high-tech industry. Industrial Management \& Data Systems, 112(1), 42-63.

Liu, S. (2010). The Study on the Relationship between Business Strategy Type and Service Innovative Performance. Paper presented at the E-Product E-Service and E-Entertainment (ICEEE), 2010 International Conference on.

Madhoushi, M., Sadati, A., Delavari, H., Mehdivand, M., \& Mihandost, R. (2011). Entrepreneurial orientation and innovation performance: The mediating role of knowledge management. Asian Journal of Business Management, 3(4), 310-316.

Mantere, S., Schildt, H. A., \& Sillince, J. A. (2012). Reversal of strategic change. Academy of Management Journal, 55(1), 172-196.

Massaro, M., Handley, K., Bagnoli, C., \& Dumay, J. (2016). Knowledge management in small and medium enterprises: a structured literature review. Journal of knowledge management, 20(2), 258-291.

Menguc, B., \& Auh, S. (2005). A test of strategic orientation formation versus strategic orientation implementation: The influence of TMT functional diversity and inter-functional coordination. Journal of Marketing Theory and Practice, 13(2), 4-19.

Miles, R. E., \& Snow. (1978). Organizational Strategy, Structure, and Process. New York: McGraw-Hill.

Mintzberg, H. (1973). Strategy-making in three modes. California Management Review, 16(2), 44-53.

Mintzberg, H. (1979). The structuring of organization: A synthesis of the research: Prentice-Hall.

Mishchuk, H., Bilan, Y., \& Pavlushenko, L. (2016). Knowledge Management Systems: Issues in Enterprise Human Capital Management Implementation in Transition Economy. Polish Journal of Management Studies, 14(1), 163173.

Narver, J. C., \& Slater, S. F. (1990). The effect of a market orientation on business profitability. The Journal of Marketing, 20-35.

Nastaran, T., Reza, E., \& Mohammad, D. (2014). Customer knowledge management, innovation capability and business performance: a case study of the banking industry. Journal of knowledge management, 18(3), 591-610. doi:doi:10.1108/JKM-11-2013-0446

Nieves, J., Quintana, A., \& Osorio, J. (2016). Organizational knowledge, dynamic capabilities and innovation in the hotel industry. Tourism and Hospitality Research, 16(2), 158-171.

O'Regan, N., \& Ghobadian, A. (2005). Innovation in SMEs: the impact of strategic orientation and environmental perceptions. International Journal of Productivity and Performance Management, 54(2), 81-97.

P. Pleshko, L., A. Heiens, R., \& Peev, P. (2014). The impact of strategic consistency on market share and ROA. International Journal of Bank Marketing, 32(3), 176-193.

Pawlowsky, P., \& Schmid, S. (2012). Interrelations between strategic orientation, knowledge management, innovation and performance. Empirical findings from a national survey in Germany. International Journal of Knowledge Management Studies, 5(1-2), 185-209.

Porter, M. E. (1980). Competitive Strategy New York. Google Scholar. 
Porter, M. E. (1985). Competitive advantage free press. New York.

Potecea, V., \& Cebuc, G. (2011). The importance of innovation in international business. The USV Annals of Economics and Public Administration, 10(3), 157-161.

Poór, J., Juhász, T., Machová, R., Bencsik, A., \& Bilan, S. (2018). Knowledge management in human resource management: Foreign-owned subsidiaries' practices in four CEE countries. Journal of International Studies, 11(3), 295-308. doi:10.14254/2071-8330.2018/11-3/23

Rastogi, P. (2000). Knowledge management and intellectual capital-the new virtuous reality of competitiveness. Human systems management, 19(1), 39-48.

Ritala, P., Henttonen, K., Salojärvi, H., Sainio, L.-M., \& Saarenketo, S. (2013). Gone fishing for knowledge? The effect of strategic orientations on the scope of open knowledge search. Baltic Journal of Management, 8(3), 328-348.

Rollins, M., \& Halinen, A. (2005). Customer knowledge management competence: Towards a theoretical framework. Paper presented at the System Sciences, 2005. HICSS'05. Proceedings of the 38th Annual Hawaii International Conference on.

Sanaz, K., Mona, J. P., \& Hossein, M. (2017). Successful customer knowledge management implementation through social media capabilities. VINE Journal of Information and Knowledge Management Systems, 47(3), 353-371. doi:doi:10.1108/VJIKMS-11-2016-0066

Sharma, P., Davcik, N. S., \& Pillai, K. G. (2016). Product innovation as a mediator in the impact of R\&D expenditure and brand equity on marketing performance. Journal of Business Research, 69(12), 5662-5669.

Slater, S. F., Olson, E. M., \& Hult, G. T. M. (2006). The moderating influence of strategic orientation on the strategy formation capability-performance relationship. Strategic Management Journal, 27(12), 1221-1231.

Slotegraaf, R. J., \& Pauwels, K. (2008). The impact of brand equity and innovation on the long-term effectiveness of promotions. Journal of Marketing Research, 45(3), 293-306.

Song, M., Nason, R. W., \& Di Benedetto, C. A. (2008). Distinctive marketing and information technology capabilities and strategic types: A cross-national investigation. Journal of International Marketing, 16(1), 4-38.

Spanjol, J., Mühlmeier, S., \& Tomczak, T. (2012). Strategic orientation and product innovation: Exploring a decompositional approach. Journal of Product Innovation Management, 29(6), 967-985.

Stevanović, M., Marjanović, D., \& Štorga, M. (2016). Idea management in product innovation-the empirical research results. Tehnički vjesnik: znanstveno-stručni časopis tebničkih fakulteta Sveučilišta u Osijeku, 23(5), 1285-1294.

Taherparvar, N., Esmaeilpour, R., \& Dostar, M. (2014). Customer knowledge management, innovation capability and business performance: a case study of the banking industry. Journal of knowledge management, 18(3), 591-610.

Tseng, S. M., \& Fang, Y. Y. (2015). Customer Knowledge Management Performance Index. Knowledge and Process Management, 22(2), 68-77.

Tung, L. (2004). Knowledge management: An exploratory study on manufacturing companies in Penang. Unpublished MBA dissertation, Olympia College Penang, Nottingham Trent University, United Kingdom.

Tutar, H., Nart, S., \& Bingöl, D. (2015). The effects of strategic orientations on innovation capabilities and market performance: the case of ASEM. Procedia-Social and Behavioral Sciences, 207, 709-719.

Venkatraman, N. (1989). Strategic orientation of business enterprises: The construct, dimensionality, and measurement. Management science, 35(8), 942-962.

Voit, S., Tkachenko, V., \& Oleshkevich, I. (2018). Intellectual potential as a means of reproduction and renewal of the unity of productive forces and industrial relations. Economics, Management and Sustainability, 3(1), 34-43.

Watkins, K., \& Marsick, V. (1996). In action. Creating the Learning Organization. Alexandria VA: American Society for Training and Development.

Yu-Pei, W., Meng-Ying, H., \& Li-Ke, L. (2016). Impact of Customer Knowledge Management on Enterprise Innovation Performance. DEStech Transactions on Engineering and Technology Research(sste).

Zaefarian, G., Forkmann, S., Mitręga, M., \& Henneberg, S. C. (2017). A capability perspective on relationship ending and its impact on product innovation success and firm performance. Long Range Planning, 50(2), 184-199.

Zheng, W., Yang, B., \& McLean, G. N. (2010). Linking organizational culture, structure, strategy, and organizational effectiveness: Mediating role of knowledge management. Journal of Business Research, 63(7), 763-771.

Zhou, K. Z., Yim, C. K., \& Tse, D. K. (2005). The effects of strategic orientations on technology-and market-based breakthrough innovations. Journal of marketing, 69(2), 42-60. 